\title{
Sivistystyö sopeuttamisen ja voimaannuttamisen ristipaineessa
}

\begin{abstract}
¥
Vapaan sivistystyön rehtorit arvioivat haastatteluissa, mitä ja keitä varten vapaata sivistystyötä tehdään. Tulosten perusteella vapaalla sivistystyöllä ei ole selkeää yhtenäistä identiteettiä, sillä se elää ajassa. Monien mielestä tärkeää on kuitenkin ihmisten hyvinvoinnin tukeminen.
\end{abstract}

PYSTYYKÖ VAPAA sivistystyö vastaamaan huomisen sivistystarpeisiin? Kysymys on sinällään ajaton, mutta näyttäisi nousseen uudelleen esiin viimeisten vuosikymmenten aikana (esim. Niemelä 2002; Salo 2004; Sihvonen 1996; Toiviainen 2002). Vapaa sivistystyö syntyi vastaamaan teollistuvan agraariyhteiskunnan sivistystarpeisiin. Nykyään, talouden merkityksen, työelämän välittömien tarpeiden sekä myöhäismodernin epävarmuuden korostuessa sivistyksen ideaali ja pyrkimys näyttäisivät menettäneen alkuperäisen merkityksensä. Gustavsson (1991, 59-61) erottaa toisistaan sivistyksen aatteen ja sitä toteuttamaan pyrkivät organisaatiot. Aatteen institutionalisoituessa se muuttuu. Vapaa sivistystyö on esimerkki institutionalisoituneesta aatteesta. Mutta voisiko se silti ammentaa sisältöä nykypäivään ja tulevaisuuteen omasta perinnöstään ja alkuperäisestä tarkoitukses- taan? Pyrin vastaamaan tähän kysymykseen tarkastelemalla ensinnäkin, miten nykyiset vapaan sivistystyön toimijat määrittelevät tehtävänsä suhteessa sen sisältöön ja kohderyhmiin sekä miten he hahmottavat toiminnan tulevaisuuden.

Olettamukseni on, että vapaata sivistystyötä on mahdollista tutkia yhtenä, aikuiskoulutuksessa erityistä tehtävää toteuttavana kokonaisuutena. Tämän voi toki kyseenalaistaa (Salo 2004), mutta pidän vapaan sivistystyön organisaatiomuotojen samankaltaisuuksia niiden eroavaisuuksia merkittävämpänä. Vapaus määritellä omat sivistykselliset tehtävänsä sekä toiminnan sisällöt ilman ulkopuolisia oppisuunnitelmia tai selkeitä tavoitteenasetteluja on esimerkki toimintaa määrittävistä samankaltaisuuksista. Vapaan sivistystyön erityisyyden ja organisatoris-hallinnollisen kokonaisuuden voi hahmottaa lainsäädännön perusteella. Se muodostuu (laki vapaasta sivistys- 
työstä 1765/2009), viidestä organisaatiomuodosta, jotka yhdessä muodostavat vapaan sivistystyön kentän. Näitä oppilaitoksia ovat kansalaisopistot, kansanopistot, kesäyliopistot, liikunnan koulutuskeskukset ja opintokeskukset. Vapaa sivistystyö "järjestää elinikäisen oppimisen periaatteen pohjalta yhteiskunnan eheyttä, tasa-arvoa ja aktiivista kansalaisuutta tukevaa koulutusta”. Sen tehtävänä on sekä edistää yksilöiden kehittymistä että kansanvaltaisuuden toteutumista monikulttuurisessa ja kansainvälisessä ympäristössä. "Vapaassa sivistystyössä korostuu omaehtoinen oppiminen, yhteisöllisyys ja osallisuus." (1765/2009)

Lain määritelmä on sinänsä ajaton ja heijastaa pohjoismaiselle kansansivistystyölle ominaisia piirteitä, joita ovat esimerkiksi humanistinen arvofilosofia, persoonallisuuden kehittäminen yleissivistyksen kautta, kansalaisten vapaaehtoinen osallistuminen sekä demokratian ja tasavertaisuuden edistäminen. Opinnoista ei saa todistuksia, toiminta saa valtiontukea, mutta voi silti vapaasti määritellä omat päämääränsä. (Alanen 1985, 10; Alanen 1986, 54-62; Niemelä 1998 \& 2011; Sihvonen 1996; Tuomisto 2002, 26-28).

Vapaa sivistystyö voi toteuttaa yllämainittuja päämäriään joko sopeuttavin tai voimaannuttavin lähtökohdin ja vapaa sivistystyö näyttäisi pitkälti omaksuneen sopeuttavan roolin (Manninen 2010). Myös Valkonen ja Kauppila (2010) tulevat vastaavaan tulokseen tutkiessaan kansalaisopiston henkilökunnan kokemuksia markkinaperusteisesta aikuiskoulutuspolitiikasta. Vapaan sivistystyön sivistysperinteen ja aikuiskoulutuksen välineellisyyden ja tehokkuuden korostumisen välillä on selkeä jännite. Sivistystyö on kallistumassa kysyntälähtöisyyden ja siten sopeutumisen puolelle ulkoisten pakotteiden, lähinnä kuntien resurssijaon ja tulosvastuullisuuden, johdosta.

\section{HAASTEENA IDENTITEETTIKRIISI}

Vapaa sivistystyö vaikuttaa olevan identiteettikriisissä (Salo 2004, 6). Sen tarkoitusta, tehtävää ja identiteettiä on pohdittu laajalti viime vuosikymmeninä niin Suomessa kuin muissakin pohjoismaissa (esim. Gustavsson 1991, Korsgaard 1997; Niemelä 2011; Salo 2004; Sundgren 2000). Institutionalisoitumisen myötä sivistystyöstä näyttää muodostuneen hankala itsestäänselvyys. Vaikka kansansivistystyö on tärkeä ja tunnustettu osa pohjoismaisen hyvinvointivaltion rakentumista ei se ole onnistunut päivittämään tarkoitustaan ja tehtäväänsä. Osallistujatkaan eivät aina miellä toimintaa vapaaksi sivistystyöksi, eivätkä pysty tunnistamaan toiminnan taustalla olevia organisaatioita (Salo 2004, 9). Itseymmärrys vaihtelee myös kentän toimijoiden parissa, sillä kaikki vapaan sivistystyön toimijat eivät välttämättä pidä itseään kansansivistäjinä (Lang 2011).

Gustavsson (1991, 13-14; 1996) nostaa esiin koulutuksen hyödyn korostumisen. Se on omiaan lisäämään sivistystyön tehtävänmäärittelyn haasteellisuutta. Vapaa sivistystyö voisi vapauteensa perustuen haastaa hyötynäkökulman, mutta se näyttäisi kuitenkin lähteneen erikoistumisen tielle. Sivistyksen itseisarvon ja koulutuksen välinearvon välille muodostuu väistämättä jännite. Tämä saa Gustavssonin toteamaan, että kansansivistyksellä on identiteettiongelma, joka on lähinnä ideologinen. Sivistystä ei enää ymmärretä kokonaisvaltaisena prosessina, vaan se kytkeytyy yhä useammin koulutuksen tavoitteellisuuteen ja hyötyihin. Toiviaisen (2002, 18-19) mukaan vapaan sivistystyön käytännöt ovat vapaaehtoisia ainoastaan teoriassa. Ne mielletään yhä useammin peruspalveluksi ja koulutukselliseksi sijoitukseksi. Vapaa sivistystyö on kuitenkin Toiviaisen mukaan ennen kaikkea yksi demokraattisen yhteiskunnan peruspilareista, jonka tulisi kansalaisten itsensä kehittämisen ohella tukea ja vahvistaa yhteiskunnan toimivuuden kannalta välttämätöntä kriittistä kansalaisaktivismia. Vapaan sivistystyön kriittiset kysymyksenasettelut ovat kuitenkin Salon ja Suorannan $(2002,179)$ mukaan olleet vähissä.

Identiteettikriisi todentuu myös suhteessa valtioon. Valtio onkin 2000-luvulla pyrkinyt selkiyttämään vapaan sivistystyön roolia ja tehtävää. Vapaan sivistystyön kehittämisohjelman 2009-2012 tarkoituksena on "vahvistaa vapaan sivistystyön oppilaitosten edellytyksiä vastata kasvaviin ja uudistuviin tehtäviin muuttuvassa toimintaympäristössä”. (Opetusministeriö, 2009.) Tämän prosessin ehkä näkyvin tulos oli uudistettu laki vapaasta sivistystyöstä. Myös suuntaviivaohjauksen tavoitteena ja koulutuspoliittisena päämääränä oli saada vapaa sivistystyö huomioimaan aiempaa selkeämmin eri marginaali- 
ryhmät, esimerkiksi maahanmuuttajat (Koulutuksen arviointineuvosto 2007).

\section{SIVISTYSTYÖN VOIMAANNUTTAVA JA SOPEUTTAVA TEHTÄVÄ}

Kiinnostus sivistystyön juuria ja identiteettiä kohtaan kertonee jotain niistä vapaan sivistystyön ja kansansivistyksen perusjännitteistä, jotka ovat määritelleet sen tavoitteita ja toimintaa läpi historian. Jännite sopeuttavan ja voimaannuttavan sivistystyön välillä on ajankohtainen vielä nykyisinkin (Manninen 2010). Alun perin kansansivistyspyrkimysten voidaan tulkita jakautuvan kriittisiin ja sopeuttaviin. Kriittiset liikkeet voidaan liittää esimerkiksi työväenliikkeen poliittisiin pyrkimyksiin. Sopeuttava sivistystyö pyrki välttämään suuria yhteiskunnallisia muutoksia ja ylläpitämään konsensusta. Sen päämääränä oli reformoida yhteiskuntaa vähitellen ja ylläpitää kansallista yhteenkuuluvuuden tunnetta. (Korsgaard 1997; Koski 2011; Toiviainen 2002; Tøsse 2002).

Pohjoismaisella sivistystyöllä on Gustavssonin (1991) mukaan juurensa kahdessa eri sivistysnäkemyksessä. Ihaileva (beundrande) suhtautuminen viittaa sivistystyöhön, joka tukee sivistyneistön sivistyskäsitystä. Ihaileva asenne ei antanut kansalle vapautta märïitellä omia sivistyksellisiä tavoitteitaan, vaan sille jaettiin sivistystä ylhäältä käsin (Korsgaard 1997). Kriittisessä suuntauksessa kansa määrittää sivistystyölle omien tarpeidensa ja tavoitteidensa mukaisen sisällön (Korsgaard 1997; Tuomisto 2002, 23-24). Ihaileva suhtautuminen voidaan tulkita yhdeksi sopeuttavan sivistystyön ilmenemismuodoksi, kun taas kriittinen suhtautuminen ilmentää voimaannuttavaa tehtävää. Sivistystyön tehtävä kansallisuusaatteen näkökulmasta oli saattaa kansa tietoiseksi itsestään. Kansanopisto oli tämän luomisprosessin tärkein väline, etenkin Tanskassa. Nuoret oppivat kansanopistossa tuntemaan omaa kieltään, kulttuuriaan ja kansaansa. (Granö \& Wallén 2003, 45-53; Gustavsson 1991, 61-63; Korsgaard 1997, 178-179; Koski 2011; Tøsse 2002, 285.) Sosialistisen sivistystyön tehtävä oli saada työläiset tiedostamaan oma asemansa ja antaa välineitä sen maltilliseen tai radikaaliin muuttamiseen. (Karjalainen \& Toiviainen 1984, 25; Korsgaard 1997, 233; Tøsse 2005, 62-63)
Vapaa sivistystyö voi siis olla sekä voimaannuttavaa että sopeuttavaa. Voimaannuttava sivistystyö on luonteeltaan kriittistä tai ainakin transformatiivista ja sen päämääränä on muutos jossain mielessä (vertaa englannin emancipation). Sopeuttava sivistystyö on puolestaan nykytilaa ylläpitävää ja vahvistavaa ja päämääränä on nykytilan säilyminen tai korkeintaan asteittainen kehittäminen. Jossain määrin nämä kaksi suuntausta voinevat elää rinta rinnan, mutta luultavasti toinen on aina tietyssä kontekstissa voimakkaammin havaittavissa.

Gustavsson (1991) hahmottaa vastaavan perusjännitteen kuvaillessaan sivistystä kolmen eri jänniteparin avulla. Sivistys on jatkuvaa taistelua prosessin ja päämäärän, elitismin ja tasa-arvon sekä erikoistumisen ja yleisen sivistyksen välillä. Sivistyksen voi toisaalta nähdä vapaana ja jatkuvana prosessina, mutta myös tiettyyn esikuvaan ja päämäärään tähtäävänä toimintana. Toinen jännite vallitsee uushumanismin tasa-arvoaatteen ja valistuksen elitistisen sivistysnäkemyksen välillä. Kolmanneksi sivistys voidaan ymmärtää kokonaisvaltaisuutta korostavana vaihtoehtona erikoistuneelle tieteelliselle tiedolle. Manninen (2010) päätyy toteamaan, että nykyisellään sivistystyön vaikutukset ovat lähinnä sopeuttavia. $\mathrm{Ne}$ painottuvat yksilön selviytymiseen ja sopeutumiseen muuttuvassa yhteiskunnassa ja erilaisissa elämäntilanteisissa. Opinnot saavat osallistujat tuntemaan mielihyvää ja jaksamaan paremmin, mutta niitä ei ymmärretä yhteisöllisyyttä lisäävinä tai kriittisyyttä herättävinä. Gustavssonin (1991) termejä käyttäen sivistystyöstä näyttäisi kadonneen prosessi-, tasa-arvo- ja yleistä sivistystä korostava näkökulma.

Salo (2004, 122-149) kuvaa vapaan sivistystyön tulevaisuutta kolmen tulevaisuusportin (utgångar) avulla. Nämä ovat kehitystä tukeva, toimintakykyä ylläpitävä ja muutosorientoitunut tulevaisuusportti. Näistä kolmesta kaksi ensimmäistä muistuttavat toisiaan ja ne voidaan yllä kuvatun mukaisesti luokitella sopeuttavaksi sivistystyöksi. Ne eivät edellytä sivistystyöltä selkeää tehtävän määrittelyä. Muutosorientoitunut on näistä kolmesta radikaalein ja voimaannuttavin.

Kehitystä tukevan vapaan sivistystyön tehtävänä on työelämän kannalta hyödyllisten kurssien järjes- 
täminen, työntekijöiden osaamisen edistäminen ja jaksamisen ylläpitäminen. Lähtökohtana on ihmisten oma-aloitteisuus omassa elämässään. Sivistystyön odotetaan tuottavan välineitä, joita kansalaiset tarvitsevat selvitäkseen ristiriitaisessa yhteiskunnassa. Niiden avulla he voivat myös markkinoida itseään työmarkkinoilla. Toimintakykyä ylläpitävä vapaa sivistystyö keskittyy perinteiden, esimerkiksi kädentaitojen, vaalimiseen. Sivistystyön keskiössä ovat joko yksittäiset yksilöt tai yhteiskunta. Toimintakykyä ylläpitävällä sivistystyöllä on myös terapeuttisia piirteitä. Se pyrkii järjestyksen luomiseen ja ylläpitämiseen monimuotoisessa ja alati muuttuvassa yhteiskunnassa.

Muutosorientoitunut vapaa sivistystyö on näistä kolmesta sitoutumattomin. Siinä on yhteiskunnallisen aktivismin piirteitä ja se pyrkii vaikuttamaan yhteiskunnan kehityksen suuntaan. Tätä suuntausta voidaan myös nimittää vapaan sivistystyön alkuperäiseksi suuntautumiseksi. Muutosorientoitunut vapaa sivistystyö on kahteen muuhun verrattuna varteen otettava vaihtoehto olemassa olevalle aikuiskasvatustoiminnalle, koska se on niistä selkeästi poliittisin.

1960-luvulta lähtien vapaa sivistystyö on pyrkinyt legitimoimaan toimintaansa kehittämällä siitä vakavamielistä (Niemelä 2002; 2011). Tähän on pyritty opinnollisuutta ja tavoitteellisuutta edistämällä. Viihtyvyyttä ja sosiaalisuutta on pidetty joko ongelmallisena tai toissijaisena seikkana. Samanaikaisesti "vapaa kansansivistystyö" muuttui pelkäksi vapaaksi sivistystyöksi Suomessa. Niemelä olettaa kansan katoamisen liittyvän sivistystyön yksilöllistämiseen. Myös muissa Pohjoismaissa ilmeni vastaavia tendenssejä, mutta vain Suomessa kansa-etuliite katosi kokonaan. Kansan ja vapauden ongelmallinen suhde oli ilmeisesti tullut tiensä päähän. Lang $(2011,19)$ esittää kansan katoamiselle kaksi tulkintaa. "Suomen kansaa yhdistävä, puhdistava ja jalostava kansansivistysprojekti" oli päättynyt vanhanaikaisena. Toinen tulkinta on, että demokratisoituneessa ja tasa-arvoisessa yhteiskunnassa oli yksinkertaisesti epämuodikasta puhua kansasta.

Niemelän (2002) mukaan vapaan sivistystyön 1960-luvulla alkaneen modernisoinnin jälkeen sen perinnöstä on jäänyt jäljelle ainoastaan vapaus. Vapaalla sivistystyöllä on vapaus itse määritellä tehtä- vänsä. Käytännössä vapaus on merkinnyt lähinnä yhteiskunnallisen suojaverkkoon syntyneiden reikien paikkaamista, ts. sivistystoiminnan järjestämistä marginaaliryhmille. Väitöskirjassaan Niemelä (2011) kuvailee sivistystyön paradigman muutosta, jonka hän tulkitsee ilmenevän 2010 voimaantulleessa laissa vapaasta sivistystyöstä. Uudessa lakitekstissä painottuu sivistystyön yhteisöllinen ja yhteiskunnallinen tehtävä. Niemelän mukaan sivistys määrittyy yksilölliseksi ja omaehtoiseksi prosessiksi, joka tapahtuu yhteisöllisessä ja vuorovaikutuksellisessa ympäristössä. Koska sivistys on prosessiluonteista, se on luonteeltaan luovaa ja ennalta arvaamatonta. Niemelää $(2002,2011)$ voi tulkita siten, että 1960-luvulla alkanut persoonallisen ja siten sopeuttavan sivistystyön aikakausi on taittumassa ja olemme uuden sivistyksellisen ja voimaannuttavan aikakauden alussa.

\section{TUTKIMUSAINEISTO JA -METODI}

Vapaan sivistystyön tulevaisuuden haasteita, sen tehtävää, kohderyhmää ja roolia tarkastellaan kentän toimijoilta kerätyn haastatteluaineiston avulla. Aineisto kerättiin loppukesästä 2010 haastattelemalla yhdeksää vapaan sivistystyön toimijaa Vaasan seudulla, Pohjanmaan maakunnassa. Näkökulma sivistystyöhön on näin ollen alueellinen, ja kyseessä on tietyssä mielessä alueellista vapaan sivistystyön toimijaverkostoa koskeva tapaustutkimus. Haastatellut edustavat kaikkia viittä vapaan sivistystyön organisaatiomuotoa Vaasan kaupungissa sekä Mustasaaren, Maalahden ja Vöyrin kunnissa. Organisaatiot sijaitsevat noin seitsemänkymmenen kilometrin laajuisella alueella, pääosa niistä kuitenkin aivan Vaasan keskustassa tai sen välittömässä läheisyydessä. Haastateltavat ovat rehtoreita tai toiminnanjohtajia neljässä kansalaisopistossa, kahdessa kansanopistossa, yhdessä opintokeskuksessa, yhdessä kesäyliopistossa ja yhdessä liikunnan koulutuskeskuksessa. Organisaatiot toimivat pääosin ruotsin kielellä, mutta mukana on myös kaksikielisiä ja yksi suomenkielinen organisaatio. Aiempi tutkimus antaa viitteitä siitä, että vapaan sivistystyön verkosto on vahvempi ja osallistuminen on aktiivisempaa ruotsinkielisen vähemmistön parissa (Salo 1999; Vaherva ym. 2006, $55,83)$ ja sivistysharrastusten merkitys on tärkeä so- 
siaalisen pääoman ja identiteetin kannalta (Hyyppä 2002).

Seitsemän haastattelua tehtiin ruotsiksi ja kaksi suomeksi. Haastattelut olivat puolistrukturoituja. Niissä käsiteltiin neljää teemaa; vapaan sivistystyön tehtävää ja luonnetta, kohderyhmiä, organisaatioiden välistä yhteistyötä sekä toiminnan tulevaisuutta. Tämän tyyppisen tapaustutkimuksen tarkoitus on lisätä ymmärrystä tietystä aiheesta tarkastelemalla yhtä rajattua ilmiötä. Tutkimuksen kohteeksi valittu ryhmä on syvällisen analyysin kohteena, mikä mahdollistaa yksityiskohtien tarkastelun. Tapaustutkimuksen rajoituksiin kuuluu, etteivät sen tulokset ole suoraan yleistettävissä. Tämä ei myöskään ole tarkoitus, koska tapaustutkimuksessa tutkittavan ilmiön erityispiirteet ovat kiinnostuksen kohteena. Tuloksena saadaan tiheä kuvaus ilmiöstä. (Merriam 1994).

Haastattelujen analysoinnissa hyödynnettiin diskurssianalyyttista otetta. Sen avulla ei tutkita ilmiöiden objektiivista luonnetta, vaan sitä, miten toimijat kuvailevat tiettyä ilmiötä ja mitä seurauksia nämä kuvaukset saavat. Toisin märiteltynä: "diskurssianalyysi on kielenkäytön ja muun merkitysvälitteisen toiminnan tutkimusta, jossa analysoidaan yksityiskohtaisesti sitä, miten sosiaalista todellisuutta tuotetaan erilaisissa sosiaalisissa käytännöissä” (Suoninen 1999, 18-19). Diskurssianalyysin lähtökohtana on inhimillisen kanssakäymisen tarkastelu sosiaalisen konstruktionismin näkökulmasta. Sen mukaan todellisuutta ei voi tutkia muulla tavalla kuin merkityksellistettynä. Merkityksellistämisessä on läsnä kaksi vastakkaista prosessia; merkitysten vakiinnuttaminen, jonka avulla voidaan olettaa, että muut ymmärtävät käsitteiden sisällön, sekä merkitysten muuntuminen, moninaistuminen ja merkityksellistämisen tapojen muuttuminen. (Jokinen 1999, 39.)

Diskurssien luomisessa huomio kiinnittyy toimijoiden tapaan hahmottaa ja luoda todellisuutta kielenkäytössä. Diskurssi asettaa ikään kuin rajat sille, mitä pidetään mahdollisena ja mahdottomana tai toivottavana ja ei-toivottuna (Bergström \& Boréus 2005). Diskurssi-käsitettä käyttämällä haluan osoittaa, että tietyllä kielenkäytöllä puhuja konstruoi oman henkilökohtaisen tai ammatillisen käsityksensä tutkimuksen kohteena olevasta todellisuudesta.
Diskurssin avulla luotuja kuvia voi olla useita, vaikka kyseessä olisi yksi ja sama ilmiö. Kielenkäyttöä muuttamalla ilmiöt merkityskellistyvät eri tavoin. Tietyn diskurssin puitteissa toimijat, tässä tapauksessa esimerkiksi rehtorit, luovat itselleen tiettyjä mahdollisia ja ainakin tietyssä määrin johdonmukaisia käsityksiä vapaasta sivistystyöstä.

Diskurssianalyysi kiinnittyy moniin eri keskustelumalleihin. Taylorin $(2001,39)$ mukaan on luultavasti mahdotonta päästä pisteeseen, jolloin tietty diskurssiaineisto olisi loppuun analysoitu. Tämä tarkoittaa, että on hylättävä tietyt mallit ja keskityttävä toisiin. Olen esimerkiksi tietoisesti sivuuttanut diskurssit, jotka koskevat vapaan sivistystyön oppilaitosmuotojen eroja, mahdollisia oppilaitosten yhdistymisiä sekä toiminnan yksi- tai kaksikielisyyttä (suomi-ruotsi). Analyysi päättyi yhdeksän diskursiivisen vastakohtaparin tunnistamiseen, jotka sekä määrittävät että rajaavat sen monimuotoisen kentän, jonka puitteissa tämän tutkimuksen vapaan sivistysyön toimijat oman toimintansa määrittävät ja merkityksellistävät.

Alun perin pyrin haastattelujen avulla tunnistamaan vapaan sivistystyön pienimmän yhteisen nimittäjän eli muotoilemaan vastauksen kysymykseen, mitä vapaa sivistystyö on? Oletin kykeneväni tunnistamaan ja kuvaamaan ainakin jossain määrin yleisen ja yhteisen kuvan vapaasta sivistystyöstä. Vastakohdat ja jännitteet osoittautuivat kuitenkin selkeämmiksi kuin yhtäläisyydet. Pyrkimys yhden yhteisen vapaan sivistystyön kertomuksen luomiseen paljasti aineiston sisäiset jännitteet, jotka kuvataan seuraavassa vastakohtaparien avulla. Osa tulkitsemistani diskursseista ilmeni kaikissa haastatteluissa, osa vain muutamissa. Sama henkilö saattoi konstruoida monta eri diskurssia tai hyödyntää vastakohtaparien molempaa ääripäätä samassa asiayhteydessä. Pääosa diskursseista oli tunnistettavissa kaikissa haastatteluissa. Haastatteluaineiston sisällöllinen monipuolisuus oli ylipäätään hyvin laaja. Tämä ilmeni heti haastattelujen alussa pyytäessäni haastateltavia kuvaamaan edellistä lukuvuotta ja pohtimaan tulevaa. Toimintaan liittyvät yksinkertaiset ja arkiset kysymykset johtivat mitä moninaisimpiin vastauksiin ja loivat huomattavan määrän erilaisia jännitteisiä diskursseja. 
Kuvio 1 alla kokoaa aineistoon sisältyvät jännitteet kahden ulottuvuuden jäsentämäksi diskurssikentäksi. Kuvioon kootut käsitteet hahmottavat ja rajaavat nämä kaksi tutkijan aineiston perusteella konstruoimaa jännitteistä ja toisensa haastavaa diskurssia. Yksinkertaistettu jäsennys nostaa liiankin vahvasti esiin aineistoon sisältyvät, yksiulotteisina esitetyt jännitteet. Ne voidaan kuitenkin tulkita myös toiminnan monimuotoisuuden ja dynaamisuuden ilmentäjinä. Diskurssikentän eri positiot voidaan Manniseen (2010) viitaten nimetä sopeuttavaksi ja voimaannuttavaksi tai Salon (2004) tulevaisuusportteja hyödyntäen pragmaattiseksi (kehitystä tukeva, toimintakykyä ylläpitävä) ja ideologiseksi (muutosorientoitunut). Lisäksi vastakohtaparit ilmentävät aktiivista ja passiivista ulottuvuutta, riippuen siitä, näkevätkö haastatellut roolinsa toiminnan kehittämisessä ensi- vai toisarvoisena.

\section{VAPAAN SIVISTYSTYÖN TEHTÄVÄT}

Viisi vastakohtaparia, joiden avulla vapaan sivistystyön tehtävät aineistossa hahmottuvat, ovat: perinteitä vaaliva - uutta luova, välineellinen - itseisarvoinen, neutraali - arvoperustainen, vapaaehtoinen hakeva sekä valtion ohjaama - luovuuden ohjaama.

\section{Perinteitä vaaliva - uutta luova}

Uuden tieto- ja viestintäteknologian luomat mahdollisuudet ovat aineistossa usein toistuva teema.
"Olemme kehittäneet sähköisiä palveluita kurssilaisillemme (1)."

On tärkeää käyttää uusia apuvälineitä tiedotukseen ja yhteydenpitoon.

"Kun ihmiset saavat vastata sähköisesti, saamme todella paljon vastauksia. [...] Meidän pitää siis ehdottomasti olla mukana siellä, missä digitaalisia asioita tapahtuu. [...] Ulkopuolelle jääminen ei ole vaihtoehto (2)."

Kehityksen seuraamisen rinnalle asettuu perinnesidonnaisuus, jota haastateltavat tulkitsevat voimavarana.

"Mutta siinä on myös jotain hyvää, että rakenne on aika kiinteä. Se antaa tiettyä vakautta ja turvallisuutta (4)."

Aineistosta löytyy lausuntoja, joissa todetaan organisaation luoneen vaalimisen arvoisia perinteitä:

"Helpointahan on pysyä siinä, missä ollaan siitä yksinkertaisesta syystä, että silloin tiedämme missä menemme ja mikä on toimiva rakenne (3)."

Perinteen vaaliminen ja uudistumisen tarve kulkevat usein rinta rinnan:

"Olen myös sitä mieltä, että - vaikka olen myös vakuuttunut siitä, että meidän on koko ajan muistettava, että yhteiskunta menee eteenpäin - olemme kulttuurin ja perinteiden ylläpitäjä (4)."
Kuvio 1. Vapaan sivistystyön kaksi diskurssikenttää.

\section{VAPAAN SIVISTYSTYÖN TEHTÄVÄT}

PRAGMAATTINEN/SOPEUTT
perinteitä vaaliva
välineellinen
neutraali
Vapaaehtoinen
valtion ohjaama
kaikille avoin
etäisyys ympäristöön
organisaatio
yksilö

Aktiivinen

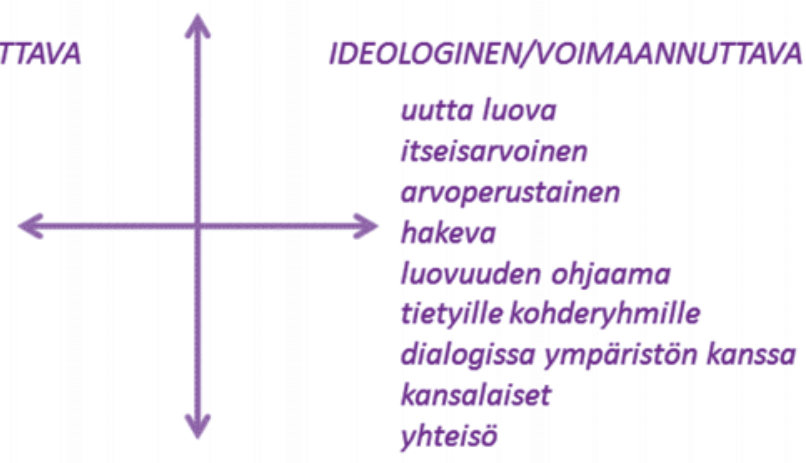

Passiivinen 
Vapaa sivistystyö voi myös välittää taitoja, joita nykyyhteiskunnassa tarvitaan, mutta joita kaikilla ei ole ollut mahdollisuuksia oppia.

"Kyllä meidän tehtävänämme on ehkäistä syrjäytymistä ja antaa työkaluja siihen, miten pysyä mukana tässä muuttuvassa yhteiskunnassa (8)."

\section{Välineellinen - itseisarvo}

Itseisarvon ja välineellisyyden ei tarvitse välttämättä olla toistensa vastakohtia vaikkakin niiden välille syntyy selkeä jännite. Vapaa sivistystyö voi perustua joko yksilöiden mielekkyyden tunteen vaalimiseen tai palvella työmarkkinoiden tarpeita ja vaatimuksia. Jos lähtökohtana ovat yksilön tarpeet, herää kysymys, halutaanko yksilölle todellakin tarjota jotain mielekästä, vai halutaanko hänen suoriutuvan tehokkaammin työelämässä?

Monet haastatelluista pitävät vapaan sivistystyön tehtävänä ihmisten hyvinvoinnin tukemista.

"Minun mielestäni tärkein tehtävä on edistää ja tukea hyvää elämää ja ihmisten hyvinvointia (9)."

Myös sivistystyön rooli työelämän vastapainona nousee usein esiin.

"[Vapaa sivistystyö] voi myös olla henkireikä, saa tehdä jotain ihan muuta (4)."

Työelämää kuvataan haastavana ja siksi vapaata sivistystyötä tarvitaan vastapainoksi.

"Nykyään on niin hektistä, ja stressaavaa ...että ihmiset kokisivat vähän iloa ja saisivat mahdollisuuden rentoutua ja saavat tuntea itsensä, että he saavat mahdollisuuden kasvattaa itsetuntoaan (5)."

Vastauksiin sisältyy myös selkeää hyötyajattelua:

"[Vapaa sivistystyö toimii] ennaltaehkäisevänäihmisethän voivat paremmin, jos he ovat aktivisia vapaa-ajallaan. Voidaan ajatella, että näkyisi nopeasti sosiaali- ja terveydenhoitokuluissa, jos tämäntyyppistä toimintaa ei olisi olemassa (6)."

Joissakin kommenteissa on normatiivinen vivahde. Vapaan sivistystyön tarjonnan pitää tukea ihmisten hyvinvointia. "...meidän tulee kyetä tarjoamaan vaihtoehto kodin sohvalle ja televisiolle ja tietokoneelle (4)."

Vapaan sivistystyön on myös kannettava tietty vastuu toiminnan vakavamielisyydestä:

"Perinteinen vapaan sivistystyön tärkeä arvohan on ollut, että toiminta on opinnollista (9)."

Joissakin lausunnoissa huvi ja hyöty nähdään myös kolikon kääntöpuolina.

"En näe vastakkainasettelua oikean oppimisen, todellisen kehittymisen, eteenpäin vievän prosessin ja opiskelun mielekkyyden välillä, vaan minusta nämä kulkevat käsi kädessä, niiden kuuluu kulkea käsi kädessä. Ihminen ei opi vähemmän, päinvastoin, ihminen oppii enemmän jos on mukavaa (1)."

\section{Neutraali - arvoperustainen}

Vapaalle sivistystyölle annetaan laissa oikeus painottaa arvoperustaansa. Tämä ei kuitenkaan ole toiminnan edellytys. Tästä huolimatta voidaan olettaa, että jokaisella organisaatiolla on oltava jonkinlainen yleisinhimillinen arvoperusta. Nämä arvot voivat perustua tasa-arvoon, suvaitsevaisuuteen ja oikeudenmukaisuuteen. Yksi esimerkki demokraattisesta arvoperustasta voisi olla, jos vapaa sivistystyö ryhtyisi tukemaan aktiivista kansalaisuutta

\section{"...haluaisin herättää keskustelua (4)."}

Aineistosta nousee selkeästi esiin tietynlainen pyrkimys neutraaliuteen sekä pyrkimys tarjota jokaiselle jotain. Käytännössä tämä voi tarkoittaa samaa kuin pyrkimys olla herättämättä närää. Se voidaan myös toisaalta tulkita kannanottona yleismaailmallisten ihmisoikeuksien puolesta.

"Ei saa unohtaa, että tämä on paikka, jonne kaikki ovat tervetulleita, kunkin taustasta riippumatta (4)."

"Kaikilla pitää olla mahdollisuus [osallistua kurssille] (7)."

Eräs toimijoista painottaa selkeästi ihmisen kunnioittamisen tärkeyttä. 
"[Vapaan sivistystyön tulee rakentua] suvaitsevaisuudelle ja huomaavaisuudelle... ja humanismille. Ja ehkä myös juuri... kestävälle elämäntavalle - pyrkimykseen elää niin hyvin kuin mahdollista (5)."

\section{Vapaaehtoinen - hakeva}

Jotkut ryhmät hakeutuvat vapaaseen sivistystyöhön toisia ryhmiä aktiivisemmin. Tavoittaakseen laajemmin eri väestöryhmiä sivistystyö voi olla luonteeltaan hakevaa. Hakevan toiminnan tarpeellisuudesta ja välttämättömyydestä ollaan eri mieltä. Toisaalta vastaajat painottavat sivistystyön vapaaehtoisuutta, toisaalta osallistumattomien tavoittaminen nähdään sivistystehtävänä.

"Voidaan aina kysyä, että onko se ongelma ja kenen ongelma [jos kaikki väestöryhmät eivät ole edustettuina]. ...Mutta minusta meillä ei ole vastuuta houkutella millä hinnalla tahansa (1)."

Vapaaehtoisuus ei välttämättä ole itseisarvo:

"Ei ole oikein myöskään se, että vapaan sivistystyön tarjonta kohdistuu vain niille, jotka osaavat sitä hakea. Tämä on kyllä minun mielestäni aika isokin haaste - miten tavoittaa uusia kohderyhmiä (9)."

Useimmissa argumenteissa korostetaan vapaan tahdon merkitystä.

"Tämä on sellaista, minkä ihminen valitsee omasta mielenkiinnostaan (2)."

Osallistuminen ei saa perustua pakkoon.

"Tässä systeemissä ei ole mitään holhousta, vaan me korostamme yksittäisen yksilön omaa tahtoa ja itsetuntoa (1)."

Yleisellä tasolla vapaan sivistystyön vapaaehtoisuus voidaan nähdä periaatteellisena kysymyksenä.

"Demokratiassahan toiminta on vapaaehtoista. Ja sehän tarkoittaa myös sitä, että jos se, jonka kanssa keskustelet, ei halua keskustella kanssasi, ei keskustelua voi syntyä (3)."

\section{Valtion ohjaama - luovuuden ohjaama}

Vapaan sivistyksen olemukseen liittyen haastatelta- vat painottavat vapaan sivistystyön vapautta oppisuunnitelmista ja muista ulkoisista pakotteista.

"Ei tämä olisi samaa jos pakotettaisiin - jos olisi oppisuunnitelma, jota pitäisi seurata (5).

Myös joustavuus nousee usein esiin.

"Ehkä tämä on vähän niin kuin jalkapallossa, on olemassa monia pelaajia, joilla on omat roolinsa, ja he ovat sidottuja näihin rooleihinsa. Vapaassa sivistystyössä liikutaan koko kentällä (3)."

Kuvatessaan mennyttä toimintavuotta monet toimijoista käyttivät määrällisiä muotoiluja.

"Näyttää hyvältä. Meillä on ollut paljon aktiviteettejä, paljon ihmisiä, paljon kursseja (1)."

Onnistuminen määrittyy toiminnan volyymin kautta, menestystä voidaan mitata valtionosuuksien avulla. Vaikka valtio ei ohjaa vapaata sivistystyötä sääntöohjauksen avulla, voidaan sen tulosohjaus tulkita sitäkin tiukemmaksi.

Monet haastatelluista toimijoista viittaavat suoraan lain ja valtion ohjauksen merkityksen.

"...koska se on yksi asioista, joihin ministeriö haluaa meidän satsaavan (2)."

Vapaan sivistystyön tehtävä määrittyy voimassa olevien lakien kautta.

"Suomessahan on laki ja lainsä̈ä̈ntö, jotka määrittävät, mitä vapaa sivistystyö meidän kannaltamme ja meidän ammatissamme on ja sieltä se määritelmä on otettava (6)."

Nämä valtiolliset kehykset rajoittavat paljon mainittua joustavuutta.

"On monta kertaa illuusio, että voimme tehdä mitä meitä huvittaa (9)."

Yksi haastateltavista tähdensi lain tulkinnanvaraa.

"Minusta raja on kyllä hyvin venyvä, ellei muuta (4)."

\section{VAPAAN SIVISTYSTYÖN KOHDERYHMÄT}

Se, miten vastaajat kuvaavat toiminnan kohderyhmää voidaan tiivistää neljään vastakohtapariin. Nämä 
ovat: kaikille avoin - tietyille kohderyhmille, etäisyys ympäristöön - dialogissa ympäristön kanssa, organisaatio - kansalaiset ja yksilö - yhteisö.

\section{Kaikille avoin - tietyille kohderyhmille}

Vaikka suurin osa tarjonnasta on periaatteessa kaikille avointa, pyrkivät toimijat eri keinoin tavoittamaan tiettyjä kohderyhmiä, esimerkiksi nuoria, ikääntyviä, miehiä ja maahanmuuttajia. Välineinä ovat markkinointi, kurssitarjonnan kohdentaminen ja imagoon vaikuttaminen.

"Olemme menneet Facebookiin, koska yritämme tavoittaa erityisesti nuoria (8)."

Toimenpiteitä voidaan myös pitää tarpeettomina. Kurssitarjontaa saatetaan esimerkiksi ajatella miehille suunnattuna, ja syyt heidän vähäiseen osallistumiseensa löytyvät jostain muualta.

"Minun mielestäni meidän kurssitarjontamme palvelee sekä miehiä että naisia. Miesten poissaolo on monen tekijän summa, mutta en näe sitä kovin ongelmallisena (1)."

Vapaan sivistystyön ei tule kuitenkaan suuntautua ainoastaan erityisryhmiin

"...minusta muut [kuin riskiryhmät] tarvitsevatja myös muilla pitää olla oikeus vapaaseen sivistystyöhön (7)."

Vaikka halu ja tahto huomioida eritysryhmät ilmenevät koko aineistossa, olennaista on vapaan sivistystyön avoimuus kaikille.

"Että kaikilla on mahdollisuus mielekkääseen tekemiseen vapaa-ajallaan - ja se, että tänne on niin äärettömän helppoa tulla (4)."

Avoimuus ilmenee myös siten, ettei vapaan sivistystyön puitteissa aseteta ulkoisia vaatimuksia eikä jaeta arvosanoja.

"Tämän kentän jännittävä puoli on se, ettei ketään ole antamassa sinulle arvosanoja. Ei ole niitä vaatimuksia ja sitä kilpailua, jota chkä joskus löytyy koulusta (4)."

Avoimuuteen ja saavutettavuuteen kuuluu myös paikallisuus: "..tämä toiminta perustuu läheisyyteen ja paikallisuuteen (5)."

Saavutettavuus perustuu myös valtiontuen mahdollistamiin alhaisiin osallistumismaksuihin.

\section{Etäisyys ympäristöön - dialogissa ympäristön kanssa}

Uusi tekniikka on mahdollistanut entistä tiiviimmän vuoropuhelun opiskelijoiden kanssa.

"Yksi tulos, jonka olemme saaneet tämän sähköisen arvioinnin kautta, on lisääntyneet kurssitoivomuk$\operatorname{set}(1) . "$

Yhteydenpitoa opiskelijoihin painotetaan haastatteluissa useaan otteeseen. Toimijoilla on vahva usko siihen, että heidän toivomuksiaan on tarkoituksenmukaista toteuttaa.

"He voivat todella pitkälle itse vaikuttaa siihen, mitä täallä tapahtuu (4)."

Vuoropuhelua ei silti aina haluta:

"Meillä on keskustelu [Facebookissa] erillisellä sivulla se on meidän virallinen tiedotuskanavamme eikä mikään avoin mielipidesivusto (1).”

Haastateltavien mielestä on tärkeää seurata ajassa liikkuvia ilmiöitä osallistujien houkuttelemiseksi.

"Kokeilemme kaikenlaisia trendejä, yritämme järjestää sellaisia kursseja, joista massat ovat kiinnostuneita (6)."

Kaikkia toiveita ei voida täyttää, koska kurssitarjontaa rajoittavat resurssit ja realiteetit.

"Yksi rajoittava seikka on henkilökunnan osaaminen (1)."

Mutta henkilökunta on myös tärkeä resurssi kurssitarjonnan kehittämisessä:

"...tieto kehitystarpeista tulee esiin näissä yleisissä keskusteluissa, joita meillä käydään täällä sisäisesti (2)."

"Mutta - sitten on tietysti myös niin, että kaikkia tarpeita ei ilmaista (1)."

Haastateltavat pitävät jatkuvaa ennakointia tärkeänä osana toiminnan kehittämistä. 
"Mitä yhteiskunnassa tapahtuu? Mitä on vireillä? Mistä lehdissä kirjoitetaan? Entä miten viime vuosi meni? Mitä tarpeita me näemme sen jälkeen (1)?"

Ennakointia on myös pitää silmällä, mitä muut tekevät:

"Seuraamme muiden kurssiohjelmia siinä määrin missä ehdimme, ja saamme niistä monia ideoita (5)."

\section{Organisaatio - kansalaiset}

Voi vaikuttaa itsestään selvältä, että organisaatiot ovat osallistujia varten. Aineistosta löytyy kuitenkin esimerkkejä diskursseista, jotka liittyvät oman organisaation säilyttämiseen. Instituutioiden itsesuojeluvaistoa painottavien esimerkkien lisäksi aineistosta löytyy myös sellaisia diskursseja, jotka painottavat kansalaisten kiinnostusten ja tarpeiden ensisijaisuutta.

Vaikuttaa siltä, että monien mielestä laaja osallistuminen on vahva syy jatkaa kuten ennenkin.

"Olemme sattumoisin saaneet paljon osallistujia, joten olemme jatkaneet sillä tavalla (7)."

Ehkä tämä näkökulma johtuu tunteesta, että raha on kaiken mitta.

"Sanoisin, että raha vaikuttaa meidän harjoittamassamme toiminnassa kaikkeen (6)."

Organisaatiorakenne voidaan myös nähdä välineenä elävän vapaan sivistystyön toteutumiseksi.

"Vapaan sivistystyön toteuttamiseen tarvitaan paikallisia intressejä ja voimavaroja. Tämä liittyy kasvatukseen ja sivistykseen, hyvin vähäisessä määrin puolueettomuuteen Jos ajateltaisiin, että [vapaassa sivistystyössä] olisi vain yksi toimija - en valitettavasti usko, että se toimisi (2)."

\section{Yksilö - yhteisö}

Tässä analyysissä esitellyistä vastakohtapareista yksilön ja yhteisön välinen jännite on ehkä vaikeimmin tunnistettavissa. Vaikka yksilö tunnistaa oman henkilökohtaisen kehityksensä, se ei tarkoita, että sosiaalinen kanssakäyminen olisi poissuljettua. Silti ero sosiaalisen kanssakäymisen ja yksilöllisyyden painottamisen välillä näyttää vaikuttavan toiminnan lähtökohtiin. Yksilöllisyyden ja yhteisöllisyyden samanaikainen painottaminen on yksi vapaan sivistystyön tunnusmerkeistä.

"Tämän tyyppistä toimintaa tarvitaan ehdottomasti, jotta ihmiset voivat jollain tavalla saada viettää mielekästä vapaa-aikaa ja ehkä kehittyä ihmisinä. Ja sosiaalinen osuus on hyvin tärkeä (5)."

Yksilöllisen kehityksen merkitystä vapaassa sivistystyössä painotetaan monessa vastauksessa.

"Tavoitteena on nimenomaan semmoinen oppiminen, ihmisenä kasvaminen, kehittyminen, uusien taitojen hankkiminen ja itsensä sivistäminen, jos nyt näin voi sanoa (9)."

Monet haastateltavista ovat sitä mieltä, että vapaan sivistystyön tehtävänä on edistää yhteisöllisyyttä ja sosiaalista kanssakäymistä.

"Vapaa sivistystyö on välittämistä ja vastuun kantamista - se lisää yhteisöllisyyden tunnetta (2)."

Yhteisöllisyyteen sisältyy myös maahanmuuttajien kotouttaminen, joka mainitaan yhtenä tärkeänä tehtävänä. Tai yleisemmin:

"[Vapaan sivistystyön pitää] ennaltaehkäistä syrjäytymistä (8)."

Yhteisöllisyyttä tulee tukea sekä paikallisesti että kansallisesti:

"Vapaalla sivistystyöllä on minun mielestäni aika iso merkitys tällaisessa - ehkä on vähän liioiteltua sanoa - yhteiskuntarauhan ylläpitämisessä (9).”

\section{SIVISTYSTYÖN ROOLI}

Haastatteluaineistosta tulkitsemani diskurssit vapaan sivistystyön sisällöstä ja kohteesta ilmentävät erilaisia käsityksiä sivistystyön roolista ja tehtävänmäärittelyn lähtökohdista. Käytän seuraavassa yhteenvedossa Mannisen (2010) käsitteitä sopeuttava ja voimaannuttava kuvaillakseni sivistystyön kahta osittain vastakohtaista tehtävänmäärittelyn lähtökohtaa. Jännite sopeuttavan ja voimaannuttavan sivistystyön välillä 
on nähtävissä myös esimerkiksi Salon (2004) kuvailemassa kolmessa mahdollisessa "tulevaisuusportissa".

\section{Sopeuttava rooli}

Vapaan sivistystyön sopeuttava tehtävänkuva ilmenee haastatteluaineistossa erinäisten kehitystä tukevien toimintamuotojen kuvailuissa. Kutakuinkin kaikki haastateltavat pitävät tärkeänä, että vapaa sivistystyö seuraa yleistä kehitystä ja pyrkii edistämään osaamisen kehittämistä. Kommenteissa nousee silti esiin tietty epävarmuus ja ulkopuolisuus.

"Jotain on varmaan tulossa tuolla nopeasti muuttuvassa tieto- ja viestintätekniikassa (5)."

Perinteitä vaaliva vapaa sivistystyö ei välttämättä sulje pois kehitystä tukevaa tehtävää.

"Jos me pidämme mielessä sen, että meidän pitää ylläpitää perinteitä ja kulttuuria - se on tärkeäämeidän pitää myös koko ajan muistaa, että aikuisväestöllä tulee olemaan myös muita sivistystarpeita [tulevaisuudessa] (4)."

Halukkuus ja tarve seurata poliittisia päätöksiä ja kotouttamiskoulutuksen järjestäminen ovat esimerkkejä kehityksen tukemisesta. Eräs tyypillinen sopeuttava tehtävä on vapaan sivistystyön rooli hektisen ja haastavan työelämän vastapainona.

"On oltava olemassa jotain tällaista, muutenhan ihmiset eivät jaksa elää (5)."

Riskinä on, että vapaasta sivistystyöstä tulee yksi niistä työkaluista, joilla tuetaan työntekijää rasittavaa työelämää.

\section{"Kulttuurin ja perinteiden kantajan (4)"}

Rooli voidaan nähdä sopeuttavana tehtävänä. Tällöin vapaan sivistystyön tehtävänä on vaalia kulttuuriperinteitä ja paikallisia erityispiirteitä.

\section{Voimaannuttava rooli}

Vapaan sivistystyön voimaannuttavaa tehtävää ja asemaa ilmentäviä puhetapoja on aineistossa rajatusti. Jotkut haastateltavien lausunnoista ilmentävät epäsuorasti voimaannuttavaa mahdollisuutta, jos tilanne vain olisi suotuisampi.
"[Vapaa sivistystyö] on meidän koulutusjärjestelmässämme paitsiossa, noin yhteiskunnallisesti nähtynä (2).”

Vaikka voimaannuttavan roolin potentiaali siis olisikin olemassa, sitä on nykytilanteessa haasteellista toteuttaa. Ylipäätään haastateltavat vaikuttavat kuitenkin suhtautuvan luottavaisesti tulevaisuuteen. Vapaan sivistystyön sopeutumiskykyyn, kurssitoiveisiin ja omaan vaistoon luotetaan.

"Muutokset näemme jo nyt ... ei ole olemassa kristallipalloa, emmekä voi ottaa sitä esiin, emme voi suunnitella kymmentä vuotta etukäteen, että näin tulemme toimimaan vuonna 2020 (1)."

Jotkut haastateltavista eivät puolestaan muutoksia tunnista tai tunnusta:

"Kaikkihan jatkuu niin kuin ennenkin... (3)."

Yllä mainittu rooli hektisen työelämän vastapainona voidaan myös tulkita voimaannuttavan tehtävän määrittelynä. Tämä edellyttää niin sanottujen heikkojen signaalien tunnistamista.

"Siitä on paljon puhuttu, että tulevaisuudessa pääoma on aikaa, tämmöistä hiljaisuutta ja hitautta. Minusta tuntuu, että siinä on jonkinlaisia avaimia tulevaisuuden sivistystarpeisiin (9)."

Lausuma ilmentää ainakin jossain määrin globaalin kilpailun sekä informaation ylitarjonnan tuottamia haasteita sekä niihin vastaamista vaihtoehtoja tarjoamalla.

\section{POHDINTA}

Vapaata sivistystyötä voidaan kuvata moninaiseksi ja jännitteiseksi aikuiskasvatuksen kentäksi. Moninaisuus perustuu toiminnan vapauteen, jota eri toimijat tulkitsevat ja toteuttavat eri tavoin, joskus myös toisilleen vastakohtaisista lähtökohdista. Organisaatiot ja niiden tehtävät, toiminta ja aatteet eivät aina kohtaa. Aineistoa kerätessä oli kiinnostavaa huomata, että osa haastateltavista ilmaisi huolensa omasta kyvystään osallistua tämänkaltaiseen tutkimukseen ja vastata esittämiini kysymyksiin. Mistä tällainen epävarmuus voisi johtua? Ovatko tämänkaltaiset tut- 
kimushaastattelut haastavia ja suorituspaineita herättäviä? Vai viestiikö epävarmuus vapaan sivistystyön identiteettiin liittyvistä haasteista? Haastateltavien epävarmuus ilmentää ehkä myös sitä, että vapaasta sivistystyöstä puuttuu yksiselitteiset vastaukset sen tavoitteista ja toiminnan sisällöistä.

Vapauteensa perustuen sivistystyö on pakotettu pohtimaan ja etsimään omaa rooliaan ja tehtäviään. Jos näin on, onko tämä ongelma? Ehkä jatkuva keskustelu vapaan sivistystyön tehtävästä ja luonteesta riittää.

Aikaisemmissa tutkimuksissa eri tavoin ilmitullut jännite sopeuttavan ja voimaannuttavan sivistystyön välillä näyttäytyy myös tässä pienehkössä alueellisessa tapaustutkimuksessa. Käyttämäni aineisto on toki rajallinen, joten sen pohjalta saadut tulokset eivät ole yksiselitteisesti yleistettävissä. Aineiston yhdeksän rehtoria käyttävät näitä kahta eri diskurssityyppiä kertoessaan toiminnastaan. Ehkä tämä jännite kahden roolin välillä on leimallinen sivistystyölle. Jännitettä voitaneen tulkita jatkuvana sivistysprosessina, joka perustuu sekä ympäröivään maailmaan sopeutumiseen että sen kyseenalaistamiseen ja uudistamiseen (Niemelä 2011).

Suomalaisella vapaalla sivistystyöllä ei enää näyttäisi olevan yhtä selkeää ja itsenäistä tehtävää, josko sitä on koskaan ollutkaan muuna kuin ulkoa ja ylhäältä annettuna ja määriteltynä valtiollis-hallinnollisena konstruktiona (Castrén 1929; Laki vapaasta sivistystyöstä 1765/2009). Sivistystyön tehtävä on pitkälti jokaisen toimijan määriteltävissä. Se on edelleen monessa mielessä vapaata, mutta tätä vapautta on lähinnä käytetty muun koulutusverkoston paikkaamiseen (Niemelä 1998). Nykytilanne eroaa sivistystyön alkuajoista siten, että nykyisin sivistystyöllä on vakiintuneet toimintamuodot, joiden olemassaoloa kentän toimijat pyrkivät perustelemaan ja puolustamaan. Organisaatiot edustavat tietyssä mielessä saavutettuja etuja, joista ei haluta luopua. Tämänkaltainen asema on omiaan ylläpitämään sopeuttavaa lähtökohtaa.

Mitä yllä kuvatut diskurssit ja jännitteet kertovat nykyisestä suomalaisesta vapaasta sivistystyöstä? Ehkä ne ilmentävät sivistystyön joustavuutta ja monimuotoisuutta, tarvetta ja halua joustaa ja sopeutua, tarjota jokaiselle jotakin, matalin kynnyksin. Jossain joustavuuden rajat tulevat kuitenkin auttamatta vastaan. Nämä rajat kohdatessaan vapaa sivistystyö joutuu määrittelemään identiteettinsä. Silloin kentän toimijoiden on valittava, haluavatko he määritellä tehtävänsä aktiivisesti itse vai ulkoistavatko vastuun muille ja valitsevat itselleen passiivisen toteuttajan roolin.

Sivistystyön tehtävänkuva on muuttunut sen yli satavuotisen historian aikana. Alkuaikoina se oli enemmän tai vähemmän kriittistä, toimijat pyrkivät ainakin jossain määrin muuttamaan yhteiskuntaa. Nykypäivänä sivistystyötä voidaan lähinnä kuvailla yhteiskuntajärjestystä tukevaksi. Onko tämä vapaan sivistystyön toimijoiden tietoinen linjaus, josta pidetään kiinni mahdollisista muutospaineista huolimatta?

Vapaan sivistystyön identiteettiä ja historiallisia juuria on tutkittu myös aikaisemmin monessa yhteydessä. Jotta vapaa sivistystyö voisi itse aktiivisesti määritellä ja toteuttaa omat tehtävänsä, tarvittaisiin todennäköisesti myös tietoista pedagogista ja didaktista kehittämistyötä. Hyvänä esimerkkinä tästä toimii Niemelän (2011) peräänkuuluttama vapaan sivistystyön sivistyspedagogiikan uudelleenlöytäminen ja kehittäminen. Sivistystyö kehittyi aikanaan kansanliikkeistä. Uskon että on aika jalkautua arjen sivistysliikkeisiin, tutkimaan, mitä niissä tapahtuu ja mihin arjen sivistystyössä pyritään.

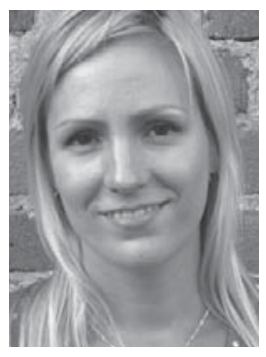

Annika Turunen

doktorand

Pedagogiska fakulteten

Åbo Akademi 
Alanen, A. (1985). Johdatus aikuiskasvatukseen. Helsinki: Yleisradio

Alanen, A. (1986). Sivistysjärjestöjen tehtäväkuvan muuttuminen 23/1986. Aikuis- ja nuorisokasvatuksen laitoksen julkaisuja. Tampere: Tampereen yliopisto

Bergström, G. \& Boréus, K. (2005). Diskursanalys. Teoksessa Bergström, G. \& Boréus, K. (toim.) Textens mening och makt. Metodbok i samhällsvetenskaplig text-och diskursanalys. Is. 305-362) Lund: Studentlitteratur

Castrén, Z. (1929). Valtio ja vapaa kansansivistystyö. Valtioneuvostolle 24.p. heinäk. 1929 annettu mietintö. Kansanvalistus ja Kirjastolehti 5-6/1929

Granö, M. \& Wallén, B. (2003). Bli någon eller något? En finlandssvensk folkbildningsodyssé. Helsingfors: Svenska folkskolans vänner

Gustavsson, B. (1991). Bildningens väg. Tre bildningsideal i svensk arbetarrörelse 1880-1930. Stockholm: Wahlström \& Widstrand

Hyyppä, M. 2002. Elinvoimaa yhteisöstä. Sosiaalinen pääoma ja terveys. Jyväskylä: PS-kustannus

Jokinen, A. (1999). Diskurssianalyysin suhde sukulaistraditioihin. Teoksessa Jokinen, A., Juhila, K. \& Suoninen, E. Diskurssianalyysi liikkeessä. (s. 37-53l Tampere: Vastapaino

Karjalainen, E. \& Toiviainen, T. (1984). Suomen vapaan kansansivistystyön vaiheet. Helsinki: Weilin+Göös

Korsgaard, 0. (1997). Kampen om lyset. Dansk voksenoplysning gennem 500 år. Köpenhamn: Gyldendal

Koski, L. (2011). Sivistystyön inmiskäsitys: Villiihmisestä aikuiseksi yksilöksi. In Valistus ja koulunpenkki. Kasvatus ja koulutus Suomessa 1860-luvulta 1960-luvulle. Helsinki: Suomalaisen Kirjallisuuden Seura.

Koulutuksen arviointineuvosto (2007). Vapaan sivistystyön vaikuttavuus ja suuntaviivaopinnot. Koulutuksen arviointineuvoston julkaisuja 25

Laki vapaasta sivistystyöstä (1765/2009) www.finlex.fi/fi/ laki/ajantasa/1998/19980632 (2.4.2013)

Lang, T. (2011). Myyttisestä sankarirehtorista opistoäidiksi ja manageriksi. Sukupuolen näkökulma kansalais- ja työväenopiston johtajuuteen. Helsingin yliopisto, Käyttäytymistieteiden laitos, Kasvatustieteellisiä tutkimuksia 235

Manninen, J. (2010). Sopeuttavaa sivistystyötä? Aikuiskasvatus, 30 (3), 164-174

Merriam, S. B. (1994). Fallstudien som forskningsmetod. Lund: Studentlitteratur.

Niemelä, S. (1998). Vapaan sivistystyön kolme tehtävää. Aikuiskasvatus, (18) 3, 218-227
Niemelä, S. (2002). Kansansivistyksen kadottaminen. Aikuiskasvatus, (22) 2, 84-91

Niemelä, S. (2011). Sivistyminen. Sivistystarve, - pedagogiikka ja politiikka pohjoismaisessa kansansivistystraditiossa. Helsinki ja Kuopio: Kansanvalistusseura ja Snellman-instituutti.

Opetusministeriö (2009). Vapaan sivistystyön kehittämisohjelma 2009-2012. Opetusministeriön asettaman valmisteluryhmän loppuraportti. Opetusministeriön työryhmämuistioita ja selvityksiä 2009:12

lwww.minedu.fi/export/sites/default/OPM/ Julkaisut/2009/liitteet/tr12.pdf?lang=fi 2.4.2013)

Salo, P. 1999. Tulivatko sivistystyöt kansalais- ja työväenopistoissa tehdyiksi? Aikuiskasvatus, 19 (4). 327-335

Salo, P. (2004). Vilken utgång - folkbildning? Texter om folkbildningens identitet och framtid. Rapport från pedagogiska fakulteten vid Åbo akademi nr 62004

Salo, P. \& Suoranta, J. (2002). Sivistyksellinen aikuiskasvatus. Helsinki: Kansanvalistusseura

Sihvonen, J. (1996). Sivistystä kaikille vai valituille? Kansalaisopistotoiminnan kehitys vapaasta kansanvalistustyöstä maksupalveluun. Tampere: Tampereen yliopisto

Sundgren, G. (2000). Demokrati och bildning. Essäer om svensk folkbildnings innebörder och särart. Borgholm: Bildningsförlaget

Suoninen, E. (1999). Näkökulmia sosiaalisen todellisuuden rakentumiseen. Teoksessa Diskurssianalyysi liikkeessä. (s. 17-36) Tampere: Vastapaino

Toiviainen, T. (2002). Vapaan sivistystyön visiot. Castrénilaista laatuviiniä uusissa tammitynnyreissä. Helsinki: Helsingin kaupungin suomenkielinen työväenopisto

Tuomisto, J. (2002). Vapaa sivistystyö 2000-luvun kynnyksellä - uudet tehtävät ja vaatimukset. Teoksessa P. Sallila \& S. Niemelä (toim.) Sivistystyö osaamisyhteiskunnassa. (s. 23-55) Helsinki: Kansanvalistusseura

Tøsse, S. (2005). Folkeopplysning og vaksenopplœring. Idear og framvekst gjennom 200 år. Oslo: Didakta Norsk Forlag

Vaherva, T., Malinen, A. Moisio, A. Raivola, R. Salo, P. Kantasalmi, K. Kamppi, P. \& Silvennoinen, H. (2006). Vapaan sivistystyön rakenne ja palvelukyky. Jyväskylä: Jyväskylän yliopisto, Koulutuksen arviointineuvosto

Valkonen, E., \& Kauppila, J. (2010). Sivistyksen keitaasta formulatalliksi? Kansalaisopiston henkilökunnan kokemuksia markkinaperusteisesta aikuiskoulutuspolitiikasta. Aikuiskasvatus, 3/2010 (s. 175-184) 